\title{
Population genetics of Hyphaene thebaica Mart., in Rabigh province, Saudi Arabia: Implications for conservation
}

\author{
Hassan Mansour 1, 2,* \\ ${ }^{1}$ Department of Biological Sciences, Rabigh-College of Science \& Art, King Abdulaziz University, Rabigh 21911, Saudi \\ Arabia. \\ ${ }^{2}$ Department of Botany, Faculty of Science, Suez Canal University, Ismailia, 41522 Egypt.
}

GSC Biological and Pharmaceutical Sciences, 2021, 17(03), 153-159

Publication history: Received on 20 November 2021; revised on 21 December 2021; accepted on 23 December 2021

Article DOI: https://doi.org/10.30574/gscbps.2021.17.3.0366

\begin{abstract}
Hyphaene thebaica is a perennial plant distributed in desert and subtropical regions of the world. In Rabigh Province, western Saudi Arabia, the few persisting populations of this species are exposed to many threats, including overcutting and, recently, human habitation. These threats are predicted to be exacerbated with the advancement of aridification caused by climate change. The conservation and revival of the diminished populations of $H$. thebaica requires an assessment of their genetic diversity and genetic differentiation. To accomplish this objective, we applied 10 simple sequence repeat (SSR) primer pairs, with which all are polymorphic loci. These polymorphic loci were used to determine the population genetics of 60 plant accessions sampled from 5 populations of $H$. thebaica located in five sites in Rabigh Province: Wadi EL Khaneg, Wadi Al Johfa, Wadi Al Hakak and Wadi Khurieba and Wadi Kuliayah . Low to moderate levels of genetic diversity were found in all populations (the values of the PPL\% ranged between $52.5 \%$ and $22.5 \%)$ along with a decreased value of HT (0.388) and a considerable inbreeding value ( F $=0.4552)$, which verified an obvious shortage of heterozygotes. High genetic differentiation among the populations and a low level of gene flow suggest isolation among the $H$. thebaica populations, which caused a severe deficiency in gene migration. The data obtained herein will inspire several recommendations for conservation the existing populations, including seed preservation, and management of human activities. All of these actions are urgently needed to prevent imminent extinction.
\end{abstract}

Keywords: Hyphaene thebaica; Conservation; Populations; Genetic diversity; Differentiation Rabigh

\section{Introduction}

Doum palm, Hyphaene thebaica Mart., (Arecaceae) is a perennial and evergreen important tree in the semiarid regions and is recognized by its dichotomous stem. It is a native species to Arabian Peninsula, sub-Saharan Africa and West India [1]. Doum fruits are used as a popular beverage and for other medicinal and industrial benefits. Also, Doum fruits are rich in fibers, antioxidants, B-complex vitamins, essential minerals as calcium, sodium and iron in the epicarp and potassium, magnesium and phosphorous in the msocarp, and have a considerable content of monosaccharides such as glucose and fructose [2]

Doum fruit aqueous extract shows anti-inflammatory, antimicrobial, anticancer and pharmacological prospective due to its major constituents like the phenolic, essential oil and flavonoid compounds [3-5]. Although, the high value of the pharmaceutical properties of plant fruits, there is a lack in exploring its genetic diversity on both morphological and molecular levels.

\footnotetext{
* Corresponding author: Hassan Mansour

Department of Biological Sciences, Rabigh-College of Science \& Art, King Abdulaziz University, Rabigh 21911, Saudi Arabia. 
The distribution of $H$. thebaica is limited to valleys and hills surrounding Rabigh, western Saudi Arabia. The apparently small populations of $H$. thebaica could be argued to the increasing aridity of this environment [6]. Anthropogenic influences are likely to lead to further decline in the population sizes of $H$. thebaica and other related species [7].

Individuals of the existing $H$. thebaica populations may suffer low genetic diversity because of co-occurring genetic drift, which is a leading factor in the low fitness and the capability of populations to acclimatize to environmental dynamics [8]. Therefore, interpreting the genetics and structure of the plant populations of $H$. thebaica is necessary to conserve and improve this plant species as well as, other plant species [9].

Plant populations in arid habitats are subject to ambient risks that threaten survival, including the loss of genetic diversity, genetic drift, and inbreeding [10].

Because of global climate change and human overutilization, many plants of the Rabigh valleys, including $H$. thebaica, are threatened with extinction, owing to reductions in population size and the subsequent erosion of genetic variation. For exploring genetic diversity and genetic structure, microsatellites DNA offer precise technology of detecting molecular basis for gene variation than any other marker system, because they target well variable repeat regions of the genome, because they can be deduced as co-dominant genetic markers [11].

In the present work, the distribution pattern, genetic diversity and genetic structure outlines among and within $H$. thebaica are considered using microsatellite loci. This research will provide information on the levels of inbreeding within $H$. thebaica populations prior to the development of conservation approaches. The proposed genetic analyses of this species will be helpful to improve its existing genetic diversity

\section{Material and methods}

\subsection{Plant material}

Five populations of $H$. thebaica were sampled form five different sites in the valleys of the Rabigh region, Western Saudi Arabia (Table 1). The largest population sampled, Wadi (Valley) Wadi Kuliayah, with 15 observed individuals.The sites in Wadi Al Johfa, Wadi Kuliayah, Wadi Al Hakak, and Wadi EL Khaneg were found in eastern Rabigh city, at a distance of at least 5 kilometres from each other. Twelve plants from each population were genotyped using 10 microsatellite loci. Portions of young leaves were collected form each individual were wrapped in filter paper and kept in silica gel to maintain complete dryness until DNA extraction.

Table 1 Sites and population information, Acronyms used to refer for populations, coordinates of sites, and population size of the twenty known populations of $H$. thebaica in Region of Rabigh

\begin{tabular}{|l|l|c|c|c|}
\hline Population acronym & Population site & Longitude (E) & Latitude (N) & Total No. of individuals \\
\hline Wkha & Wadi EL Khaneg & $39^{\circ} 9^{\prime} 51.5232^{\prime \prime}$ & $22^{\circ} 45^{\prime} 1.512^{\prime \prime}$ & 13 \\
\hline Wjoh & Wadi Al Johfa & $39^{\circ} 8^{\prime} 54.290^{\prime \prime}$ & $22^{\circ} 42^{\prime} 37.336^{\prime \prime}$ & 12 \\
\hline Whak & Wadi Al Hakak & $39^{\circ} 14^{\prime} 31.3296^{\prime \prime}$ & $22^{\circ} 45^{\prime} 14.7636^{\prime \prime}$ & 12 \\
\hline Wkhb & Wadi Khurieba & $39^{\circ} 3^{\prime} 12.6252^{\prime \prime}$ & $23^{\circ} 5^{\prime} 21.2892^{\prime \prime}$ & 13 \\
\hline Wkull & Wadi Kuliayah & $22^{\circ} 26^{\prime} 13.2^{\prime \prime}$ & $39^{\circ} 10^{\prime} 47.28^{\prime \prime}$ & 15 \\
\hline
\end{tabular}

\subsection{Genomic DNA isolation and PCR amplification}

DNA was isolated from dried leaf samples using a DNeasy Plant Mini Kit (Qiagen, Switzerland). For each individual, 10 loci were tested for polymorphisms using published primers [12-13] (Table 2). PCR reactions were conducted with a master mix of $25 \mu \mathrm{l}$ containing $2.5 \mu \mathrm{l}$ of $10 \times$ reaction buffer, $1 \mu \mathrm{l}$ of $\mathrm{MgCl}_{2}(50 \mathrm{mM}), 0.5 \mu \mathrm{l}$ of a dNTP mix, $0.2 \mu \mathrm{l}$ of a forward primer (including the M13-tail $(10 \mu \mathrm{M})), 0.5 \mu \mathrm{l}$ of a reverse primer $(10 \mu \mathrm{M}), 0.5 \mu \mathrm{l}$ of the universal M13 primer $(10 \mu \mathrm{M})$ labelled with a fluorophore (FAM, NED, VIC, or PET), $0.1 \mu \mathrm{l}$ of Taq DNA polymerase (Dream Tag, Fermentas; 50 $\mathrm{U} / \mu \mathrm{l}), 1.0 \mu \mathrm{l}$ of bovine serum albumin $(20 \mathrm{mg} / \mathrm{ml}), 1.0 \mu \mathrm{l}$ of $10 \mathrm{ng} / \mu \mathrm{l}$ genomic DNA, and sterilized water up to the final volume. All the PCRs were performed as singleplex assays using a C1000 Thermal Cycler (BioRad, USA) under the following conditions: initial denaturation at $94^{\circ} \mathrm{C}$ for 5 minutes; 50 cycles of $94^{\circ} \mathrm{C}$ for 30 seconds, $55^{\circ} \mathrm{C}$ for 45 seconds and $72^{\circ} \mathrm{C}$ for 1 minute; 8 cycles of $94^{\circ} \mathrm{C}$ for 30 seconds, $53^{\circ} \mathrm{C}$ for 45 seconds, and $72^{\circ} \mathrm{C}$ for 1 minute; and a final extension step at $72^{\circ} \mathrm{C}$ for 5 minutes. The fluorescently tagged PCR products were analysed in multiplexes on a $3130 \mathrm{xl}$ Genetic 
Analyzer (Applied Biosystems, Foster City, CA, USA) using LIZ500 (Applied Biosystems, USA) as a size standard. The amplified fragments were scored using GeneMapper 4.0 (Applied Biosystems, USA), and the lengths of the amplified fragments ranged from 50 to $1050 \mathrm{bp}$ according to [14].

Table 2 Information on the markers used for $H$. thebaica germplasm analysis

\begin{tabular}{|c|c|c|c|c|c|}
\hline Marker & Primer Sequence (5'-3') (F: Forward; R: Reverse) & $\mathbf{T a}($ (马) & amplicion & SSR Motif & Ref. \\
\hline sMo00018 & $\begin{array}{l}\text { F: TTAAATGAGAGAGAGACGAGGAC } \\
\text { R: TGGAGCCATGAGAAAGAGTA }\end{array}$ & 54 & 242 & (CT)14 & [12] \\
\hline sMo00020 & $\begin{array}{l}\text { F: CСТTTCTCTCССТСТCСТTTTG } \\
\text { R: CСТCССТCССТCTCACCATA }\end{array}$ & 58 & 180 & (AG)15 & \\
\hline sMo00127 & $\begin{array}{l}\text { F: GTGGTTTGGGAGAAAGAGTGT } \\
\text { R: TGCGGTGGATTAGCATTATT }\end{array}$ & 56 & 202 & (GAA)12 & \\
\hline sMo00129 & $\begin{array}{l}\text { F: TTAGTATTGGGTGTGCATAAGTGG } \\
\text { R: GCTTCCAGCTCCTCTTTCTACC }\end{array}$ & 56 & 226 & (TTC)13 & \\
\hline sMo00134 & $\begin{array}{l}\text { F:CCAATAGTCGTTACAAACCAG } \\
\text { R: TTAGCAAAAGGGCAAAAAGG }\end{array}$ & 56 & 250 & (ATTA)6 & \\
\hline sMo00137 & $\begin{array}{l}\text { F: AGGAAGGAGAAGGAGATGAACAG } \\
\text { R: CTTTGGATTTGAGCAGAGGAAG }\end{array}$ & 54 & 148 & (AAAT)6 & \\
\hline Aacu 10 & $\begin{array}{l}\text { F: TGCCACATAGAGTGCTTGCT } \\
\text { R: CTACCACATCCCCGTGAGTT }\end{array}$ & 56 & 112 & (AG)16 & [13] \\
\hline Aacu 12 & $\begin{array}{l}\text { F: GAATGTGCGTGCTCAAAATG } \\
\text { R: AATGCCAAGTGACCAAGTCC }\end{array}$ & 56 & 202 & $(\mathrm{TC}) 20$ & \\
\hline Aacu 18 & $\begin{array}{l}\text { F: TCCACCTTTAATGGGAGTGC } \\
\text { R: TAAACAGCGCCAGGTCTTCT }\end{array}$ & 56 & 223 & (TG)17 & \\
\hline Aacu 26 & $\begin{array}{l}\text { F: ACTTGCAGCCCCATATTCAG } \\
\text { R: CAGGAACAGAGGCAAGTTC }\end{array}$ & 56 & 117 & $(\mathrm{AC}) 13$ & \\
\hline
\end{tabular}

\subsection{Population genetic analysis}

The determination of the parameters of genetic diversity, genetic structure and inbreeding was performed using GenAlEx 6.1 [15]. The genetic differentiation among the populations was assessed with $R_{\mathrm{ST}}$, an equivalent to $F_{\mathrm{ST}}$ developed for microsatellite loci [16]. The genetic structure of the $H$. thebaica populations was assessed by analysis of molecular variance (AMOVA; 999 permutations) [17]. The number of reproductively successful migrants per generation $(\mathrm{Nm})$ was estimated by the private allele method [18]. The established heterozygosity $\left(H_{0}\right)$, the expected heterozygosity $\left(H_{\mathrm{e}}\right)$ under Hardy-Weinberg equilibrium, and Wright fixation index $\left(F=1-H_{\mathrm{o}} / H_{\mathrm{e}}\right)$ were assessed for each locus in each population to test deviations from the Hardy-Weinberg equilibrium, which determines inbreeding. UPGMA dendrogram using PAST 4.02 [19] (Figure 1) based on genetic diversity varibles: number of alleles $N_{a}$, number of effective alleles $N_{e}$, shanon information index $I$, number of private alleles, the expected heterozygosity $\left(H_{e}\right)$, heterozygosity $\left(H_{o}\right)$, and Percentage of Polymorphic Loci $P \%$.

\section{Results}

The total of 10 loci revealed polymorphisms. The percentage of polymorphic loci (Table 3) was the highest value $(52.5 \%)$ in Wadi EL Khaneg population, while the lowest percentage of polymorphic loci (22.5\%) was found in Wadi Khurieba population in. High selfing is suggested by our results for $H$. thebaica, as the average fixation index $(F)$ was equal to 0.455 , confirming an explicit deficit of heterozygotes (Table 3 ).

The mean number of alleles per locus $\left(N_{a}\right)$ ranged between 1.750 (Wadi EL Khaneg population) and 1.3 (in Wadi Khurieba population). The means of the effective number of alleles per locus $\left(N_{e}\right)$, Shannon's Index $(I)$, and expected heterozygosity $\left(H_{e}\right)$ varied between $1.492,0.369$, and 0.229 in the Wadi Khurieba population and 1.180, 0.144, and 0.088 in Wadi Khurieba population, respectively (Table 3.). 
Table 3 The mean values of the of genetic diversity variables across the studied populations of $H$. thebaica Na (No. of Different Alleles), Ne (No. of Effective Alleles), I (Shannon's Information Index), No. Private Alleles (No. of Alleles Unique to a Single Population), He (Expected Heterozygosity), P (the percentage of polymorphic loci), and F (fixation index) in the twenty studied populations of $H$. thebaica

\begin{tabular}{|l|l|l|l|c|l|l|l|}
\hline Population & Na & Ne & I & No. of Private Alleles & He & P\% & F \\
\hline Wkha & 1.750 & 1.492 & 0.369 & 0.250 & 0.229 & 52.50 & 0.455 \\
\hline Wjoh & 1.625 & 1.377 & 0.261 & 0.025 & 0.151 & 30.00 & 0.719 \\
\hline Whak & 1.725 & 1.430 & 0.330 & 0.175 & 0.201 & 47.50 & 0.094 \\
\hline Wkhb & 1.300 & 1.180 & 0.144 & 0.050 & 0.088 & 22.50 & 0.464 \\
\hline Wkull & 1.350 & 1.187 & 0.167 & 0.050 & 0.105 & 27.50 & 0.544 \\
\hline Overall mean & 1.55 & 1.3332 & 0.2542 & 0.11 & 0.1548 & 36 & 0.4552 \\
\hline
\end{tabular}

The average total heterozygosity $\left(H_{\mathrm{T}}\right)$ for all the loci and populations was 0.451.

The cluster analysis was shown on UPGMA dendrogram (Figure 1) subdivided into three main clusters, the first cluster including two populations one population from Al Hakak and one population from Wadi EL Khaneg, which were exhibited the highest means of genetic variables; the remaining three populations were distributed in the second cluster which contained two populations from Al Johfa site, and Wadi Kuliayah in one sub-cluster and one population from Wadi Khurieba site where this site revealed a lowest values of genetic diversity variables and geographically isolated

The AMOVA revealed considerable genetic differentiation among the studied $H$. thebaica populations $\left(F_{\mathrm{ST}}=0.363, R \mathrm{ST}=\right.$ 0.791). The highest genetic differentiation occurred among the populations $(77 \%, P=0.010)$, whereas the lowest value $(17 \%, P=0.010)$ was detected among individuals within the populations.

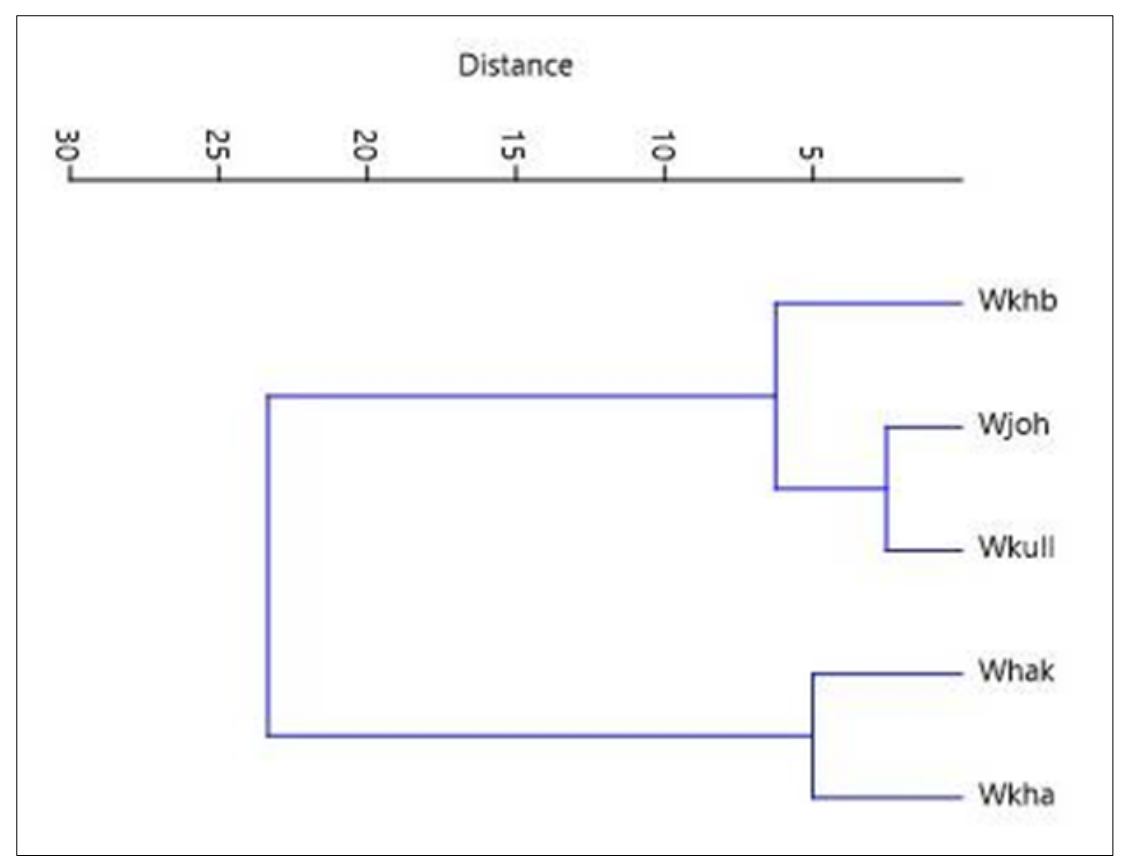

Figure 1 UPGMA dendrogram for the 5 populations of $H$. thebaica

\section{Discussion}

The analysis of 10 polymorphic loci, represnting the mean number of alleles per locus $\left(N_{a}\right)$, means of the effective number of alleles per locus $\left(N_{e}\right)$, Shannon's Index $(I)$, expected heterozygosity $\left(H_{e}\right)$, and total genetic diversity of $H$. 
thebaica, implied moderate to low genetic diversity in all the populations of $H$. thebaica. Likewise, other researches have outlined that low genetic diversity has been determined for other species with isolated and small populations [20-25].

Low polymorphism rates can be a result of a reduction in population size; therefore, genetic drift and inbreeding will aggravate the risk of genetic diversity depletion in the grown species in extreme environmental conditions [26-28]. The random allele scarcity and thus the moderate-low genetic variation found in the current research could be due to the significant recent decline in the population size of $H$. thebaica; the number of individuals ranged between 12 and 15.

The main factors for the considerable reduction in the population size of $H$. thebaica include over cutting and root removal by natives for firewood and small animal stables that are common in these locations. Last, overconsumption of underground water reserves by local residents and for recent growing industrial projects in the Rabigh region a great threat for water resources [29; 6]. Because of these anthropogenic factors, together with the predictions for upcoming higher temperature and drier conditions as a consequence of global climate change [7], $H$. thebaica is facing future extinction due to reductions in population size and the following erosion of genetic diversity.

Moreover, the direct consequence of water scarcity on plant survival, the rising in temperatures could harm the flowers of the species and subsequently impair the pollination fitness [30]. Finally, the decline of genetic diversity and gene flow among the populations might ultimately increase selfing and enhance the negative impacts of aridity. The extraordinary values of differentiation among the populations were in accordance with the extremely low value measured for gene flow among the populations $(\mathrm{Nm}=0.090)$. These findings in accordance with the high value of genetic differentiation between populations of some other rare species, including other plant species grown in arid habitats [24-31].

The deficient gene migration among the considered populations could be accredited to the inability of $H$. thebaica to spread its seeds over other distant locations due to the large size (6-8 cm height) and shape of its fruits, which confine its dispersal distance to be nearby the mother plants [32].

Therefore, the main factor of gene migration is pollen transfer in other plant species that reproduce sexually [33]. However, the negative effects of aridity on pollinator service could cause the presence of many unviable seeds. The measured value of gene flow was lower than the limit required to prevent genetic drift [34] the joint effect of genetic drift and gene flow could worsen future drop in genetic diversity of the remaining populations of $H$. thebaica

\section{Conclusion}

Our present research is considered as a first insight into the population genetics and genetic structure of $H$. thebaica in one of the most prominent regions in the western region of Saudi Arabia. Our findings specified a mild to severe loss of polymorphic genes joined with noticeable genetic differentiation and high inbreeding. Firm actions should be engaged to achieve sustainable controlling and conservation of the existing populations of $H$. thebaica in Rabigh. The restoration of populations are fundamental actions for long-term conservation programs, and they can be concluded as follows. First, cutting and removal of existing populations should be checked and managed in regions with highly endangered populations with low genetic diversity parameters, e.g., Johfa and Wadi Kuliayah valleys. Second, comprehensive programmes to reduce water consumption will be suggested, and these programmes will be publicized through media and educational institutes. Their aim will be to effectively manage underground water.

Third, the evident reduction in the genetic diversity and high genetic differentiation sustain the idea that the populations of $H$. thebaica in Rabigh could be mended mainly by inclusive seed collection from the $H$. thebaica trees of all the existing populations [35].

The collected seeds would primarily be incorporated into $H$. thebaica restoration programmes, in which the seeds will be germinated in greenhouse, and then the seedlings will be planted in highly endangered sites. The new $H$. thebaica plants will be reintroduced into habitats resembling to those of its original populations in order to inhibit consequences including forthcoming inbreeding and a severe drop in gene flow. Some of the collected seeds should be presreved using seed bank procedures; these will be supportive to continue future plans to conserve $H$. thebaica in its original habitats. 


\section{Compliance with ethical standards}

\section{Acknowledgments}

The author thanks Rami El-jahdali (Rabigh-College of Science \& Art) for valuable guidance and help during sampling of Hyphaene thebaica from the study sites in Rabigh region.

\section{Disclosure of conflict of interest}

The author has no conflict of interest (only one author for the manuscript).

\section{References}

[1] Fanshawe DB. The Dum Palm-Hyphaene hebaica (Del.) Mart. East African Agricultural and Forestry Journal. 1966; 32(2): 108-16.

[2] Aboshora W, Lianfu Z, Dahir M, Gasmalla MA, Musa A, Omer E, Thapa M. Physicochemical, nutritional and functional properties of the epicarp, flesh and pitted sample of doum fruit (Hyphaene Thebaica). Journal of Food and Nutrition Research. 2014; 2(4): 180-186.

[3] Mohamed AN. Antioxidant and anticancer activities of doum fruit extract (Hyphaene thebaica). African Journal of Pure and Applied Chemistry. 2009; 3(10), 197-201.

[4] Eldahshan OA, Ayoub NA, Singab ANB, Al-Azizi MM. Potential antioxidant phenolic metabolites from doum palm leaves. African Journal of Pharmacy and Pharmacology. 2009; 3(4): 158-164.

[5] El-Beltagi HS, Mohamed HI, Yousef HN, Fawzi EM. Biological activities of the doum palm (Hyphaene thebaica L.) extract and its bioactive components. In: Shalaby E, Azzam GM (eds). Antioxidants in foods and its applications. Intech Open, London. 2018.

[6] Tarawneh QY, Chowdhury S. Trends of Climate Change in Saudi Arabia: Implications on Water Resources. Climate. 2018; 6(8): 1-19.

[7] Soultan A, Wikelski M, Safi K. Risk of biodiversity collapse under climate change in the Afro-Arabian region. Scientific Reports. 2019; 955(9): 1-12.

[8] Bastiaan S, Hamish GS. Effects of genetic drift and gene flow on the selective maintenance of genetic variation. Genetics. 2013; 194(1): 235-244.

[9] Hatmaker EA, Staton ME, Dattilo AJ, Hadziabdic D, Rinehart TA, Schilling EE, Trigiano RN, Wadl PA. Population Structure and Genetic Diversity within the endangered species Pityopsis ruthii (Asteraceae). Frontiers in Plant Science. 2018; 9-943.

[10] Frankham R. Where are we in conservation genetics and where do we need to go? Conservation Genetics. 2010; 11(2): 661-3.

[11] Kim KS, Sappington TW. Microsatellite Data Analysis for Population Genetics. In: Kantartzi S. (eds) Microsatellites. Methods in Molecular Biology (Methods and Protocols), Humana Press, Totowa, NJ. 2013; 1006: 271-295.

[12] Zaki NM, Singh R, Rosli R, Ismail I. Elaeis oleifera genomic-SSR markers: exploitation in oil palm germplasm diversity and cross-amplification in Arecaceae. International journal of molecular sciences. 2012; 13(4): 406988.

[13] Neiva DS, Melo Júnior AF, Oliveira DA, Royo VA, Brandão MM, Menezes EV. Acrocomia emensis (Arecaceae) genetic structure and diversity using SSR molecular markers. Genetics and Molecular Research. 2016; 15(1): 1-1.

[14] Arif IA, Khan HA, Shobrak M, Al Homaidan AA, Al Sadoon M, Al Farhan AH, Bahkali AH. Interpretation of electrophoretograms of seven microsatellite loci to determine the genetic diversity of the Arabian Oryx. Genetics and Molecular Research. 2010; 9: 259-265.

[15] Peakall R, Smouse PE. GenAlEx v.6.5: Genetic analysis in Excel. Population genetic software for teaching and research. Bioinformatics. 2012; 28: 2537-2539.

[16] Slatkin M. A measure of population subdivision based on microsatellite allele frequencies. Genetics. 1995; 139: 457-462. 
[17] Excoffier L, Smouse PE, Quattro JM. Analysis of molecular variance inferred from metric distances among DNA haplotypes: application to human mitochondrial DNA restriction data. Genetics. 1992; 131: 479-491.

[18] Barton NH, Slatkin M. A quasi-equilibrium theory of the distribution of rare alleles in a subdivided population. Heredity. 1986; 56(3): 409-15.

[19] Hammer $\varnothing$, Harper DAT, Ryan PD. PAST: Paleontological statistics software package for education and data analysis. Palaeontologia Electronica. 2001; 4(1): 9.

[20] Hamrick JL, Godt MJW, Sherman-Broyles SL. Factors influencing levels of genetic diversity in woody plant species. New Forest. 1992; 6: 95-124.

[21] Crowford, DJ, Ruiz E, Stuessy T F, Tepe E, Aqeveque P, Gonzalez F, Jensen R J, Anderson GJ, Bernardello G, Baeza $\mathrm{CM}$, Swenson U, Silva M. Allozyme diversity in endemic flowering plant species of the Juan Fernandez Archipelago, Chile: Ecological and historical factors with implications for conservation. American Journal of Botany. 2011; 88: 2195-2203.

[22] Hirai M, Kubo N, Ohsako T, Utsumi T. Genetic diversity in the endangered coastal violet Viola grayi Franchet et Savatier (Violaceae) and its genetic relationship to the species in subsection Rostratae. Conservation Genetics. 2012; 13: 837-848.

[23] Mansour H, Bryngelsson T, Garkava-Gustavsson L. Development, characterization and transferability of 10 novel microsatellite markers in Cotoneaster orbicularis Schltdl. (Rosaceae). Journal of Genetics. 2016; 95: e9-e12.

[24] Mansour H, Sliwinska E. Genetic Diversity and Inbreeding Level of Cotoneaster orbicularis Schltdl. in The Sinai Mountains Revealed by Microsatellite Markers and Flow Cytometry. Egyptian Journal of Botany. 2017; (57)2: 351- 361.

[25] Mansour H, Alsamadany H, Al-Hasawi ZM. Genetic diversity and genetic structure of Salvadora persica L., rare plant species in Rabigh province, Saudi Arabia: Implications for conservation. Journal of Taibah University for Science. 2020; 14(1): 881-8.

[26] Blomqvist D, Pauliny A, Larsson M, Flodin LA. Trapped in the extinction vortex? Strong genetic effects in a declining vertebrate population. BMC Evolutionary Biology. 2010; 10-33.

[27] Jacquemyn H, Roldán-Ruiz I, Honnay O. Evidence for demographic bottlenecks and limited gene flow leading to low genetic diversity in a rare thistle. Conservation Genetics. 2010; 11: 1979-1987.

[28] Smyser TJ, Duchamp JE, Johnson SA, Larkin JL, Rhodes Jr O Consequences of metapopulation collapse: comparison of genetic attributes between two Allegheny woodrat metapopulations. Conservation Genetics, 13, 849-58.

[29] Harter T, Davis H, Mathews M, Meyer R. Shallow ground water quality on dairy farms with irrigated forage crops. Journal of Contaminant Hydrology. 2002; 55: 287-315.

[30] Root TL, Price JT, Hall KR, Schneider SH, Rosenzweig C, Pounds JA. Fingerprints of global warming on wild animals and plants. Nature. 2003; 421: 57-60.

[31] Jimenez A, Mansour H, Keller B, Conti E. Low genetic diversity and a high level of inbreeding in the Sinai primrose (Primula boveana), a species on the brink of extinction. Plant Systematics and Evolution. 2014; 300: 1199-1208.

[32] Idohou R, Assogbadjo AE, Houehanou T, Kakaï RG, Agbangla C. Variation in Hyphaene thebaica Mart. fruit: physical characteristics and factors affecting seed germination and seedling growth in Benin (West Africa). The Journal of Horticultural Science and Biotechnology. 2015; 90(3): 291-6.

[33] Hylmö B, Fryer J. Cotoneasters in Europe. Acta Botanica Fennica. 1999; 162: 179-184.

[34] Spieth PT. Gene flow and genetic differentiation. Genetics. 1974; 78: 961-965.

[35] Holsinger KE, Gottlieb LD. Conservation of rare and endangered plants: principles and prospects. In: Falk DA, Holsinger KE (eds) Genetics and Conservation of Rare Plants. Oxford University Press, New York. 1991; $195-208$. 